Zeszyty Naukowe Szkoły Głównej Gospodarstwa Wiejskiego w Warszawie Problemy Rolnictwa Światowego tom 17 (XXXII), zeszyt 1, 2017: 7-18

DOI: 10.22630/PRS.2017.17.1.1

Anetta Barska ${ }^{1}$

Uniwersytet Zielonogórski

\title{
Innowacje na rynku produktów żywnościowych z perspektywy polskich i czeskich konsumentów generacji Y
}

\section{Innovations on the Market of Food Products from the Perspective of Polish and Czech Generation Y Consumers}

\begin{abstract}
Synopsis. Nowoczesny rynek produktów żywnościowych jest rynkiem o wysokim poziomie innowacyjności, co jest konsekwencją zmian otoczenia, a wraz z nimi coraz bardziej zróżnicowanych oczekiwań konsumentów. Produkty żywnościowe służą nie tylko zaspokojeniu potrzeb podstawowych, ale także różnych hedonistycznych pragnień, sprzyjają zachowaniu smukłej sylwetki, wzrostowi sił witalnych, oszczędzają czas oraz chronią środowisko (Gutkowska, 2011). Obecnie na rynku zarysowują się dwie przeciwstawne tendencje z jednej strony nasilająca się globalizacja przyczynia się do ujednolicania postaw i zachowań konsumentów, a z drugiej - nasila się rola tożsamości, co skłania do regionalizacji. Przemysł spożywczy staje się coraz bardziej globalny. Rozwój międzynarodowych korporacji, przepływ kapitału i siły roboczej w skali międzynarodowej powodują dyfuzję kultur oraz wzrost tendencji do utożsamiania się z wartościami ponadnarodowymi. Jednak zjawisko homogenizacji potrzeb jest mniej zauważalne w obrębie produktów żywnościowych. Konsumpcja żywności ma najsilniejszy związek z kulturą kraju, a zatem w stosunku do konsumpcj przemysłowej jest mniej podatna na proces globalizacji. Znajomość postaw i zachowań konsumentów wobec innowacji może w znacznym stopniu przyczynić się do wzrostu innowacyjności podmiotu. Konsument jest nieocenionym źródłem informacji, niezbędnych dla producentów, zwłaszcza tych funkcjonujących w obszarach przygranicznych, w trakcie przygotowywania strategii marketingowych związanych z projektowaniem i wprowadzaniem nowych produktów na rynek. Obecnie nie ma jednego wspólnego stanowiska, czy decyzje zakupu produktów żywnościowych przez konsumentów generacji Y są determinowane przez globalne trendy, czy też są one wynikiem uwarunkowań lokalnych. Dlatego podjeccie tego problemu badawczego znajduje swoje uzasadnienie poznawcze $z$ powodu jego niewystarczającego rozpoznania. Celem niniejszego artykułu jest identyfikacja percepcji innowacji na rynku żywnościowym przez konsumentów generacji Y. W postępowaniu badawczym wykorzystano analizę literatury przedmiotu i wyniki własnych badań przeprowadzonych wśród 606 konsumentów generacji Y, z obszarów przygranicznych Polski i Czech. Wyniki badań dowodzą, że młodzi konsumenci są otwarci na nowości. Innowacje na rynku żywności to kategoria subiektywna, a niektóre sposoby jej postrzegania były zróżnicowane ze względu na płeć oraz kraj pochodzenia respondentów.
\end{abstract}

Słowa kluczowe: globalizacja, konsument generacji Y, innowacje, produkt żywnościowy, zachowania konsumenta

\begin{abstract}
Modern food market is a market with a high level of innovativeness, what is a consequence of more and more differentiated expectations of consumers, not only about the hunger, but also various hedonistic desires, keeping slender figure, increasing vital forces, saving time, or protection of environment (Gutkowska, 2011). Food industry is becoming more and more global. Development of international corporations, movement of capital and workforce on the international scale, development of IT cause diffusion of consuming behavior patterns and there is growing tendency of identification with transnational values. However, phenomenon of homogenization of needs is less observable within the food products because consumers often manifest ethnocentric attitudes toward these
\end{abstract}

\footnotetext{
${ }^{1}$ dr inż., Wydział Ekonomii i Zarządzania Uniwersytet Zielonogórski, ul. Podgórna 50d, 65-246 Zielona Góra, e-mail:A.Barska@wez.uz.zgora.pl
} 


\begin{abstract}
products. Food consumption has the strongest relationship with the culture of the country and therefore, in comparison with industrial consumption is less susceptible to the process of globalization. Consumer is an invaluable source of information, indispensable for the producers during preparation of marketing strategies connected with designing and introduction of new products to the market. Knowledge of attitude and behaviors of the consumers towards innovations can significantly contribute to the growth of subject innovativeness. Currently, there is no single common position on how baying decisions of the Generation Y consumer are determined by global trends, and to what extent they are the result of cultural conditioning. Therefore, undertaking this issue has its cognitive justification due to insufficient diagnosis. The goal of this article is identification perception of Gen Y consumers towards innovations on the food market. The author used an analysis of the subject literature and results of her own surveys conducted among 606 consumers Generation Y, from the border areas of Poland and Czech Republic. Results of research have proven that young consumers are open to novelties. The innovations on the food market is a subjective category. Some of the ways of perception of innovations on the food market varied depending on sex and nationality of the respondents.
\end{abstract}

Key words: globalization, Generation Y consumer, innovation, food product, consumer behavior

\title{
Wprowadzenie
}

Z punktu widzenia oferentów, rynek produktów żywnościowych jest szczególnie trudny ze względu na m.in. dużą konkurencję, trudności w wyróżnieniu oferty, silne rozdrobnienie segmentów rynkowych oraz problemy w osiagnięciu akceptacji nowych produktów żywnościowych przez ich nabywców. Ponadto na rynku zarysowują się dwie przeciwstawne tendencje wobec produktów żywnościowych z jednej strony nasilająca się globalizacja przyczynia się do ujednolicania postaw i zachowań konsumentów, a z drugiej wzrasta rola tożsamości, co skłania do regionalizacji. W obliczu tych tendencji szczególnie interesujący staje się współczesny rynek młodych konsumentów, który posiada cechy konwergencyjne w skali globalnej (Parmar, 2002A; Choi, Ferle, 2004), jednak przy zachowaniu odmienności zachowań wobec produktów żywnościowych często związanych z kulturą i tradycją (Parmar, 2002B). Nie ma jednak jednolitego stanowiska w tym obszarze i wiedza $\mathrm{w}$ tym zakresie wymaga uzupełnienia, co uzasadnia podjęcie tej problematyki badawczej. Pomocne w tym zakresie stają się badania zachowań konsumentów na rynku. Pozwalają one na uzyskanie informacji niezbędnych dla producentów w trakcie opracowywania strategii marketingowych związanych $\mathrm{z}$ projektowaniem oraz wprowadzaniem na rynek nowych produktów. W tym miejscu warto przywołać stanowisko Mazurek-Łopcińskiej (2003): ,zachowania nabywców powinny być dla przedsiębiorców źródtem inspiracji oraz podstawa ksztaltowania i weryfikacji decyzji rynkowych". Znajomość postaw i zachowań konsumentów wobec innowacji może istotnie przyczynić się do wzrostu innowacyjności podmiotów. Celem niniejszego artykułu jest identyfikacja percepcji innowacji na rynku żywności z perspektywy konsumentów generacji Y z Polski i Czech. W postępowaniu badawczym wykorzystano analizę literatury przedmiotu oraz wyniki własnych badań ankietowych przeprowadzonych wśród 606 respondentów.

\section{Innowacje na rynku produktów żywnościowych}

Istotnym czynnikiem, mającym wpływ na efektywność i przewagę konkurencyjną przedsiębiorstwa działającego w zakresie przetwórstwa rolno-spożywczego jest 
innowacyjność. Może ona dotyczyć trzech obszarów: produktu, procesu technologicznego oraz organizacji pracy (Firlej i Makarska, 2012). Działania innowacyjne firm przemysłu spożywczego stają się elementem ich strategii. Efekty wdrożenia innowacyjnych rozwiazań zawsze powinny przynosić wymierne efekty, takie jak: zwiększenie udziału w rynku, zmniejszenie kosztów bezpośrednich, a w konsekwencji zwiększenie przychodów. Wdrażane zmiany mogą dotyczyć technologii przetwarzania żywności dla poprawy jej bezpieczeństwa, dla wygody jej stosowania lub walorów smakowych, mogą być również związane ze zmianą systemu dystrybucji, opakowania, czy też form promocji. Aktywność innowacyjna pozwala przedsiębiorstwom wyprzedzić swoich konkurentów na danym rynku, pozyskać nowych konsumentów, jak i zatrzymać dotychczasowych poprzez utrzymanie ich zainteresowania produktami danego producenta, a w rezultacie zdobyć stabilną pozycję w danym segmencie. Cyrek (2007) wskazuje na duży wpływ innowacyjności na konkurencyjność przedsiębiorstw przemysłu spożywczego. Autor zauważa, że nieustanne uświadamianie konieczności podejmowania nowych działań, kreowanie nowych zasad i wzorców funkcjonowania, budowanie postaw innowacyjnych, rozwijanie kompetencji i ciagłe usprawnianie bieżących działań staje się podstawą konkurencyjności rynkowej. Uwzględniając charakter działań innowacyjnych, należy uznać, że mają one wpływ na wzrost konkurencyjności gospodarki, w tym również gospodarki żywnościowej w skali globalnej, krajowej i regionalnej (Zieliński i Żmija, 2013). Rozważając problem innowacji warto zapoznać się ze znaczeniem tego terminu. Innowacje szeroko definiowali m.in. Schumpeter (1960), Allen (1966), Whitfield (1979), Haffer (1998), Rogers (2003), natomiast przedstawicielami wąskiego ujęcia są Carter i Williams (1957), Mansfield (1968), Freeman (1994). Innowacje symbolizuja zmianę, nowość, wyrażającą się pod postacią nowych produktów, nowatorskich technologii, nietradycyjnych usług czy niekonwencjonalnych metod zarządzania. Pojęcie innowacji wprowadził do nauk ekonomicznych Schumpeter (1960), rozumiał on innowacje ,jako tworzenie zmian fundamentalnych lub radykalnych, obejmujacych transformacje nowej idei lub technologicznego wynalazku $w$ rynkowy produkt lub proces". Definicja ta jest nowatorskim połączeniem kapitału i środków produkcji, obejmującym swoim zasięgiem: wprowadzenie do produkcji wyrobów nowych lub też udoskonalenie dotychczas istniejących, wprowadzenie nowej lub udoskonalonej metody produkcji, otwarcie nowego rynku, zastosowanie nowego sposobu sprzedaży lub zakupów, zastosowanie nowych surowców lub półfabrykatów oraz wprowadzenie nowej organizacji produkcji. Integralną częścią definicji innowacji, według Schumpetera, jest pierwsze zastosowanie danego rozwiązania. Badacz Rogers (2003) wskazuje, że innowacje to wszystkie dziedziny, które poprzez subiektywne odczucia rejestrowane są i oceniane jako nowość, niezależnie do realnego stopnia nowatorstwa rzeczonego przedmiotu lub myśli. Według Kotarby (1987) innowacja to: proces lub skutek procesu oceniany przez określony podmiot jako nowy i korzystny. Natomiast Freeman (1986) uważa, że innowacje to pierwsze (w rozumieniu handlowym) zastosowanie nowatorskiego produktu, procesu, systemu lub urządzenia. Szerokie ujęcie pojęcia innowacji implikuje również zróżnicowanie ich klasyfikacji przy wykorzystaniu rozmaitych kryteriów podziału (tab. 1). 
Tabela 1. Klasyfikacje innowacji

Table 1. Classification of innovation

\begin{tabular}{l|l}
\hline \multicolumn{1}{c|}{ Kryterium klasyfikacji } & \multicolumn{1}{c}{ Rodzaje } \\
\hline Dziedzina działalności & Produktowe, procesowe, organizacyjne i marketingowe \\
Wielkość i zakres skutków & $\begin{array}{l}\text { Strategiczne i taktyczne } \\
\text { Autonomiczne i indukowane }\end{array}$ \\
Pochodzenie & $\begin{array}{l}\text { Radykalne (wywołują w przedsiębiorstwie zmianę przełomowa) oraz } \\
\text { stopniowe (usprawnienie lub wprowadzanie drobnych modyfikacji) }\end{array}$ \\
Skala innowacji & $\begin{array}{l}\text { Nowość w skali świata, kraju bądź całego działu przemysłu oraz } \\
\text { przedsiębiorstwa }\end{array}$ \\
Kryterium nowości & Kreatywne i imitujące \\
\hline
\end{tabular}

Źródło: Schumpeter 1960; Freeman 1986; Penc 1999; Griffin 2004; Oslo Manual 2005; Janasz i Kozioł 2007.

$\mathrm{Na}$ zachowania innowacyjne przedsiębiorstw mają wpływ determinanty wewnętrzne i zewnętrzne. Potencjał przedsiębiorstwa utożsamiany jest $\mathrm{z}$ jego zasobami finansowymi, infrastrukturą oraz stanem wiedzy technicznej. Wdrażanie innowacji związane jest z chęcią poprawy jakości, zwiększenia wydajności, czy też wzrostu zyskowności produkcji. Uwarunkowania dotyczące otoczenia wynikają z trendów zachowań konsumenckich, a także z aspektów prawnych, ekonomicznych, technologicznych, demograficznych makrootoczenia. W szczególności należą do nich (Costa i Jongen, 2006; Gutkowska i Ozimek 2006; Adamowicz, 2008; Lenart, 2008B; Sojkin, 2012; Szwacka-Mokrzycka, 2013):

- polityka państwa i instytucji państwowych, w tym nowe rozwiązania administracyjno-prawne i instytucjonalne, uwarunkowania proinnowacyjne (np. celowe zachęty inwestycyjne, tworzenie programów rządowych wspierających innowacyjność przedsiębiorstw, budowanie kapitału ludzkiego);

- aktywność innych podmiotów gospodarczych funkcjonujących w otoczeniu firmy, niekiedy poczynania jednych przedsiębiorstw wpływają pozytywnie bądź negatywnie na stymulowanie innych przedsiębiorstw do wytwarzania innowacji;

- pozycja konkurencyjna przedsiębiorstwa na tle innych przedsiębiorstw, z którymi rywalizuje bezpośrednio lub pośrednio;

- zmiany w łańcuchu żywnościowym (np. nowe surowce, dodatki do żywności, technologie, systemy produkcyjne, materiały i urządzenie do produkcji opakowań, kanały dystrybucji);

- działalność badawczo-rozwojowa (B+R) placówek i ośrodków naukowobadawczych oraz współpraca z nimi;

- zmiany demograficzne przejawiające się spadkiem przyrostu naturalnego, wzrostem długości życia, zmniejszeniem liczebności gospodarstw domowych;

- zmiany zachowań konsumentów, w tym nowe, jeszcze niezaspokojone potrzeby konsumentów.

Analiza literatury prowadzi do wniosku, że nie ma również jednoznacznej definicji określającej pojęcie nowego produktu żywnościowego (Lenart, 2008A). Nowe produkty żywnościowe mogą powstawać poprzez: rozwój linii produktu, uzyskanie innowacyjnej formy, zmiany formy występowania istniejącego produktu, zmianę przeznaczenia, zmianę opakowania, a także przez innowację i wartość dodaną w produkcie. Przy projektowaniu 
nowych produktów żywnościowych warto pamiętać, że ich rynkowe niepowodzenia są często skutkiem niezaspokojenia oczekiwań konsumentów, nie uwzględniania ich preferencji. Przedsiębiorstwo przemysłu spożywczego, chcąc funkcjonować i odnosić sukcesy na rynku, musi umiejętnie oceniać swoje produkty z uwzględnieniem perspektywy ich nabywców, która często jest odmienna od punktu widzenia producenta, czy też norm prawnych. Zgodnie z przepisami obowiązującymi w Unii Europejskiej pojęcie nowej żywności obejmuje składniki żywności, jak i całe środki spożywcze przeznaczone do konsumpcji, w tym również środki spożywcze wzbogacone, jak również specjalnego przeznaczenia żywieniowego oraz suplementy diety. Należy uwzględniać również nowe składniki żywności takie, jak: wyekstrahowane lub składające się z drobnoustrojów, grzybów, wodorostów, roślin i składników żywności pochodzenia zwierzęcego, a także kategorię żywności o nowej lub celowo zmodyfikowanej strukturze molekularnej, czy też poddanej nowemu procesowi wytwórczemu, w wyniku którego uzyskuje się zmiany w strukturze, składzie żywności, przekładające się na wartość odżywczą środka spożywczego (Czajkowska i in., 2013). Wymienione środki spożywcze i składniki żywności nie mogą stanowić zagrożenia dla życia i zdrowia konsumentów, jak również wprowadzać ich $\mathrm{w}$ błąd. Nowa żywność podlega procedurom związanym $\mathrm{z}$ oceną bezpieczeństwa i dopuszczenia jej do obrotu określonym w artykule 92 oraz artykule 121 Ustawy z dnia 25 sierpnia 2006 r. o bezpieczeństwie żywności i żywienia (Dz.U. $2006 \mathrm{Nr}$ 171 poz. 1225 z późniejszymi zmianami). W myśl zapisów przywoływanej ustawy organem właściwym do zapewnienia przeprowadzenia postępowania dotyczącego wstępnej oceny naukowej oraz sporządzenia wstępnego sprawozdania odnośnie nowej żywności wprowadzanej do obrotu jest Główny Inspektor Sanitarny.

\section{Konsument produktów żywnościowych na globalnym rynku}

Obserwowane przeobrażenia rynku żywności wskazują na istnienie dwóch przeciwstawnych tendencji przejawiających się z jednej strony nasilająca się globalizacją, a z drugiej strony dążeniem do podkreślenia roli tożsamości, a więc swoistej regionalizacji (Giddens, 2008). Należy się zgodzić, że przemysł spożywczy staje się coraz bardziej globalnym. Rozwój korporacji międzynarodowych, przepływ kapitału i siły roboczej w skali międzynarodowej, rozwój technologii informacyjnych powodują że następuje dyfuzja wzorów zachowań konsumpcyjnych i narasta skłonność do identyfikacji z ponadnarodowymi wartościami (Rowe i in., 2011). Niewątpliwie, rozwój gospodarki rynkowej, trwający proces globalizacji, postęp technologiczny oraz wzrost poziomu życia stworzyły rodzaj kultury konsumpcyjnej, w którym ludzie dążą do jak najlepszego zaspokojenia swoich potrzeb. Uwidacznia się zanik tradycji kulturowych na rzecz ujednolicenia wzorców spożycia produktów żywnościowych. Tworzy się kultura masowa, która "jest dynamiczna, rewolucyjną siłą, która eliminuje podziały klasowe, tradycję, smak i zaciera różnice kulturowe" (Macdonald, 2002). Z drugiej strony odzwierciedleniem tendencji do regionalizacji jest rosnące zainteresowanie produktami żywnościowymi, które identyfikowane sa z określonymi obszarami geograficznymi i kulturą (Sajdakowska i Żakowska-Biemans, 2009). Kultura wpływa na przekonania i decyzje konsumentów dotyczące jakości produktów żywnościowych, może mieć również wpływ na akceptację innowacji i tym samym jej sukcesu (Steenkamp i Ter Hofstede, 2002). MazurekŁopacińska (2003) uważa, że konsumpcja żywności ma najsilniejszy związek z kulturą 
danego kraju i dlatego w porównaniu z konsumpcją przemysłową jest mniej podatna na proces globalizacji. W krajach rozwiniętych pojawiaja się trendy podkreślania swojej kulturowej unikatowości, odrębności i oryginalności, co prowadzi do wzrostu zainteresowania produktami regionalnymi (Figiel, 2004; Bartosik-Purgat, 2011; Szromnik i Wolanin-Jarosz, 2014). Jak podaje Mazurek-Łopacińska (2003), skłonność konsumentów do przyjęcia produktów globalnych zależy od siły związku z lokalną kultura. Wśród konsumentów żywności w krajach rozwiniętych, istnieje tendencja preferowania produktów $\mathrm{z}$ własnego kraju, a nabywcy $\mathrm{w}$ krajach słabo rozwiniętych często wybierają produkty zagraniczne (Figiel, 2004; Sikora, 2008). Ponadto producenci krajowi są często bardziej preferowani przez osoby starsze i z niższym wykształceniem, podczas gdy czynnik ten jest najmniej ważny dla osób z wyższym wykształceniem (Sikora, 2008).

Znajomość postaw konsumentów wobec nowej żywności stanowi cenne źródło informacji niezbędnych dla producentów $\mathrm{w}$ trakcie opracowywania strategii marketingowych związanych z projektowaniem oraz wprowadzeniem na rynek nowych wyrobów. Zalega (2016) podkreśla, że „,w dobie nowych technologii i możliwości, jakie stwarza wspótczesna gospodarka, to wtaśnie innowacyjni konsumenci kreuja rynek dla nowych marek $i$ nowych produktów, poczqtkowo przez manifestowanie ich użytkowania przed naśladowcami, a następnie poprzez popularyzowanie ich nastawienia". Podstawową przyczyną wprowadzania nowych produktów na rynek są wymagania konsumentów, co potwierdza orientację na klienta wyraźnie odzwierciedloną w działaniach w zasadzie wszystkich wytwórców produktów. Proces projektowania i wprowadzania na rynek nowych produktów żywnościowych ma na celu zaspokojenie dotychczasowy potrzeb w sposób doskonalszy bądź nowych potrzeb konsumenta, a konsumenci są bezpośrednim celem tego procesu (Earle i in., 2007).

\section{Metodyka badań}

Przeprowadzona kwerenda literatury pozwala zauważyć, że aktualnie nie ma jednego wspólnego stanowiska dotyczącego na ile spożycie żywności wśród młodych konsumentów nawiązuje do trendów globalnych, a na ile wynika $\mathrm{z}$ uwarunkowań kulturowych (Michałowska i Danielak, 2015). Dlatego też podjęcie tej problematyki znajduje uzasadnienie:

- poznawcze - z uwagi na niedostateczne jej rozpoznanie,

- aplikacyjne - zredagowane wnioski mogą zostać wykorzystane przez producentów żywności w budowaniu strategii marketingowych adresowanych do tego segmentu rynku.

Na pierwszym etapie postępowania niezbędny był przegląd dostępnych wyników badań zachowań konsumentów na rynku żywności (Gutkowska i Ozimek, 2005; JeżewskaZychowicz, 2009; Sojkin i in., 2009; Gutkowska, 2011; Kowalczuk, 2011; Barska, 2013). $\mathrm{Na}$ kolejnym etapie zrealizowano badania empiryczne, których zakres przestrzenny obejmował obszar przygraniczny zgodny z przyjętym przez Cross-Border Friendship Database. Badania miały charakter komparatywny i zastosowano podejście etic. Wykorzystana metoda badawcza to ankieta, a narzędzie pomiarowe stanowił autorski kwestionariusz ankiety zawierający 26 pytań. Na potrzeby badań na rynkach zagranicznych kwestionariusz został przetłumaczony na język ojczysty, zgodnie z zasadami thumaczenia 
zwrotnego. Badana populację stanowili przedstawiciele pokolenia Y (osoby urodzone w latach 1984-1997). Przedstawiciele pokolenia Y funkcjonują w określonych społecznościach, co może mieć poważny wpływ na ich stosunek do zakupów produktów żywnościowych. Menedżerowie marketingu muszą zrozumieć zachowanie konsumentów generacji $\mathrm{Y}$, aby skutecznie zaistnieć w tym segmencie i rozwijać innowacje, najbardziej pożądane przez tych odbiorców. Badania wstępne zostały zrealizowane w 2013 roku, natomiast zasadnicze w 2015. Weryfikacja materiału empirycznego i niekompletność danych w kwestionariuszach nieznacznie ograniczyły próbę. W wyniku tych działan 606 spośród czeskich i polskich kwestionariuszy sklasyfikowano, jako kompletne i nadające się do dalszej analizy. Zebrane dane zostały poddane redukcji i redakcji, co pozwoliło na ich analizę i interpretację. Do oceny rzetelności skal został wykorzystany test Alfa Cronbacha, który przyjął wartość powyżej 0,776 , co oznacza prawidłową rzetelność skali. W niniejszym artykule zaprezentowano jedynie niektóre wyniki badań, odnosząc je do innych badań w tym zakresie dostępnych w literaturze (Gutkowska, Ozimek, 2005; Sojkin, Małecka, Olejniczak, Bakalarska, 2009; Kowalczuk, 2011; Gutkowska, 2011; BabiczZielińska, Jeżewska-Zychowicz, Tańska, 2013 i inni].

$\mathrm{W}$ analizowanej zbiorowości:

- $60 \%$ badanych stanowili polscy konsumenci, a $40 \%$ czescy;

- $\quad 57 \%$ stanowily kobiety a $43 \%$ mężczyźni.

\section{Wyniki i dyskusja}

Dostrzegany i potwierdzany wieloma badaniami tradycjonalizm i konserwatyzm w zachowaniach konsumentów powoduje, że strategie innowacji produktowych na rynku produktów żywnościowych muszą być starannie przemyślane i zaplanowane (Sojkin i Olejniczak, 2012). Przeprowadzone badania również potwierdzają, że konsumenci deklarowali największą skłonność do decyzji nawykowych - czescy (69\% respondentów) i polscy (65\% respondentów) (tab. 2). Wcześniejsze badania autorki wykazują również, iż przyzwyczajenia żywieniowe istotnie determinują postawy nabywcze badanych, zwłaszcza polskich konsumentów, u których na piątym miejscu jako kryterium zakupu żywności pojawiły się właśnie przyzwyczajenia żywieniowe, w przypadku konsumentów pochodzących z Czech i Słowacji były to odleglejsze miejsca (Barska, 2013). Analizując płeć można zauważyć, że kobiety częściej kierują się przyzwyczajeniem, natomiast mężczyźni mają skłonność do większej analizy oferty rynkowej. Może to wynikać z faktu, że mężczyźni rzadziej dokonują zakupów produktów żywnościowych, tym samym decyzje te wymagają większego zastanowienia i pozyskania informacji.

$\mathrm{W}$ grupie badanych konsumentów generacji $\mathrm{Y}$ udział innowatorów jest znacznie większy niż w modelu Rogersa (2003) dotyczącego całej populacji, co może dowodzić, że adaptacja innowacji na rynku żywności jest zależna od wieku. Młodzi konsumenci znacznie szybciej akceptują innowacje na rynku żywności, mimo że na rynku tym konsumenci często kierują się przyzwyczajeniem, podobne wnioski wyłonili inni badacze (Sojkin, 2009; Kowalczuk, 2011; Gutkowska, 2011; Babicz-Zielińska i in., 2013; Gutkowska i in., 2014). Udział innowatorów w grupie czeskich konsumentów był ponad 2,5-krotnie większy, wczesnych naśladowców 2-krotnie mniejszy niż w polskiej grupie. Wskaźnik udziału 


\section{A. Barska}

mężczyzn niechętnych wobec nowych produktów żywnościowych był znacznie wyższy niż kobiet.

Respondenci zostali poproszenie o wyrażenie swojej opinii na temat istoty innowacji na rynku produktów żywnościowych (tab. 3). Wykorzystane w kwestionariuszu stwierdzenia określające innowacje na rynku żywności zostały wyodrębnione $\mathrm{w}$ trakcie wcześniej zrealizowanego wywiadu fokusowego.

Tabela 2. Samoocena zachowań konsumenckich na rynku żywności

Table 2. Behaviours of the respondents while purchasing food products

\begin{tabular}{l|cc}
\hline \multicolumn{1}{c|}{ Samoocena zachowań konsumenckich wobec żywności } & $\begin{array}{c}\text { Czescy } \\
\text { konsumenci } \\
(\mathrm{w} \%)\end{array}$ & $\begin{array}{c}\text { Polscy konsumenci } \\
(\mathrm{w} \%)\end{array}$ \\
\hline $\begin{array}{l}\text { Decyzje o zakupach produktów żywnościowych podejmuję pod } \\
\text { wpływem emocji }\end{array}$ & 8 & 14 \\
$\begin{array}{l}\text { Długo rozważam swoje decyzje o zakupie produktów } \\
\text { żywnościowych, wykorzystuję przy tym liczne źródła informacji } \\
\begin{array}{l}\text { Przy zakupie produktów żywnościowych kieruję się } \\
\text { przyzwyczajeniem }\end{array}\end{array}$ & 23 & 21 \\
\hline
\end{tabular}

Źródło: opracowanie własne na podstawie badań ankietowych.

Analiza uzyskanych wyników badań pozwala na sformułowanie wniosku, że kraj pochodzenia respondentów różnicuje pojmowanie innowacji produktu żywnościowego. Deklaracje czeskich respondentów były bardzo spolaryzowane, w wielu przypadkach równie liczna grupa respondentów zgadzała się, jak i sprzeciwiała niektórym sformułowaniom określającym innowacje na rynku produktów żywnościowym. Opinie polskich konsumentów były zdecydowanie bardziej jednomyślne. Polscy konsumenci za innowacje produktu żywnościowego uznawali przede wszystkim zmniejszenie poziomu sktadników niekorzystnych dla zdrowia oraz wprowadzenie nowych sposobów utrwalania żywności (bez konserwantów, bez pasteryzacji), natomiast czescy konsumenci uznawali za innowacje wprowadzanie produktu o nowym smaku, konsystencji, formie oraz zmiane składu. W tym miejscu warto dodać, że wygoda użycia i właściwości prozdrowotne produktów będą czynnikiem wymuszającym w najbliższych latach kierunek innowacji produktowych i staną się siłą napędową rozwoju polskiego sektora żywnościowego (Sojkin i in., 2009). Polscy konsumenci częściej przychylali się do opinii, że innowacjami są różne zmiany związane $\mathrm{z}$ opakowaniem, należy również zauważyć, że właśnie w tym zakresie najbardziej odmienne były opinie polskich i czeskich konsumentów.

Analizując płeć w postrzeganiu innowacji należy zwrócić uwagę, że istniała zależność statystyczna między płcią a uznaniem za innowacje produktu żywnościowego:

- zmiane wygladu opakowania (nowy ksztalt, nowa kolorystyka);

- zmniejszenie poziomu sktadników niekorzystnych dla zdrowia;

- wprowadzanie produktu o nowym smaku, konsystencji, formie;

- podawanie przez producenta nowych zastosowań produkt. 
Tabela 3. Innowacja produktu żywnościowego w opinii czeskich i polskich konsumentów

Table 3. Innovative food products in opinion of Polish and Czech consumers

\begin{tabular}{|c|c|c|c|c|c|c|}
\hline \multirow[b]{2}{*}{$\begin{array}{c}\text { Innowacja produktu } \\
\text { żywnościowego polega na: }\end{array}$} & \multicolumn{3}{|c|}{ Czescy konsumenci (w \%) } & \multicolumn{3}{|c|}{$\begin{array}{c}\text { Polscy konsumenci (w \%) } \\
\text { Ani się }\end{array}$} \\
\hline & $\begin{array}{l}\text { Nie } \\
\text { zgadzam } \\
\text { się }\end{array}$ & $\begin{array}{l}\text { Ani się nie } \\
\text { zgadzam ani } \\
\text { się zgadzam }\end{array}$ & $\begin{array}{l}\text { Zgadam } \\
\text { się }\end{array}$ & $\begin{array}{c}\text { Nie } \\
\text { zgadzam } \\
\text { się }\end{array}$ & $\begin{array}{l}\text { nie } \\
\text { zgadzam } \\
\text { ani się } \\
\text { zgadzam }\end{array}$ & $\begin{array}{l}\text { Zgadam } \\
\text { się }\end{array}$ \\
\hline Zmianie gramatury produktu* & 39 & 26 & 35 & 33 & 50 & 17 \\
\hline $\begin{array}{l}\text { Zmianie wyglądu opakowania } \\
\text { (nowy kształt, nowa } \\
\text { kolorystyka)* }\end{array}$ & 43 & 20 & 37 & 23 & 31 & 46 \\
\hline $\begin{array}{l}\text { Zmianie opakowania na } \\
\text { ekologiczne* }\end{array}$ & 36 & 21 & 43 & 10 & 23 & 67 \\
\hline $\begin{array}{l}\text { Ulepszeniu opakowania w } \\
\text { celu przedłużenia trwałości } \\
\text { produktu* }\end{array}$ & 40 & 20 & 40 & 9 & 28 & 63 \\
\hline $\begin{array}{l}\text { Wzbogaceniu produktu o } \\
\text { dodatkowe składniki* }\end{array}$ & 28 & 39 & 33 & 10 & 34 & 56 \\
\hline $\begin{array}{l}\text { Skróceniu czasu } \\
\text { przygotowania produktu do } \\
\text { spożycia* }\end{array}$ & 35 & 33 & 32 & 16 & 44 & 40 \\
\hline $\begin{array}{l}\text { Zmniejszeniu poziomu } \\
\text { składników niekorzystnych } \\
\text { dla zdrowia* }\end{array}$ & 42 & 22 & 36 & 8 & 22 & 70 \\
\hline $\begin{array}{l}\text { Zmianie marki - } \\
\text { wprowadzaniu nowej marki } \\
\text { na rynek }\end{array}$ & 34 & 36 & 30 & 31 & 44 & 25 \\
\hline $\begin{array}{l}\text { Wprowadzaniu na rynek } \\
\text { dotychczas niesprzedawanego } \\
\text { produktu* }\end{array}$ & 45 & 24 & 31 & 16 & 32 & 52 \\
\hline $\begin{array}{l}\text { Wprowadzaniu produktu o } \\
\text { nowym smaku, konsystencji, } \\
\text { formie* }\end{array}$ & 34 & 15 & 51 & 7 & 32 & 61 \\
\hline Zmianie składu produktu* & 30 & 23 & 47 & 17 & 47 & 36 \\
\hline $\begin{array}{l}\text { Wprowadzeniu nowych } \\
\text { sposobów utrwalania } \\
\text { żywności (bez konserwantów, } \\
\text { bez pasteryzacji)* }\end{array}$ & 42 & 15 & 43 & 5 & 22 & 73 \\
\hline $\begin{array}{l}\text { Podawaniu przez producenta } \\
\text { nowych zastosowań } \\
\text { produktu* }\end{array}$ & 37 & 31 & 32 & 17 & 44 & 39 \\
\hline $\begin{array}{l}\text { Wprowadzaniu zmian } \\
\text { zmierzających do ochrony } \\
\text { środowiska* }\end{array}$ & 37 & 25 & 38 & 9 & 29 & 62 \\
\hline
\end{tabular}

* istotność asymptotyczna wartość p-value jest mniejsza niż 0,05

Źródło: opracowanie własne na podstawie badań ankietowych.

Kobiety częściej zgadzały się z tymi opiniami. Największe zróżnicowanie opinii ze względu na płeć dotyczyło stanowiska, że innowacja produktu żywnościowego to skrócenie czasu przygotowania produktu do spożycia (mężczyźni częściej zgadzali się z tą opinią). 
Natomiast największa zgodność opinii ze względu na płeć dotyczyła stanowiska, że innowacja produktu żywnościowego to wzbogacenie produktu o dodatkowe składniki. Płeć wewnątrz narodowości różnicowała jedynie stosunek badanych do stwierdzenia: innowacje produktów żywnościowych polegaja na wprowadzeniu nowych sposobów utrwalania żywności (bez konserwantów, bez pasteryzacji) - w Polsce zarówno kobiety, jak i mężczyźni zgadzali się z tym stwierdzeniem, z kolei w Czechach kobiety zgadzały się natomiast mężczyźni wręcz przeciwnie (dwie wartości p-value były istotne tzn. mniejsze od 0,05). Jeżewska-Zychowicz i in. (2009) są zdania, że o postrzeganiu produktu przez konsumentów w kategorii nowości decyduje konfrontacja zmian jego cech i właściwości z potrzebami. Produkt jest nowy z punktu widzenia konsumenta, jeśli za taki go on uznaje. Poznanie oczekiwań klienta jest istotne z punku widzenia projektowania nowych wyrobów. Wobec tego szczególnego znaczenia nabiera pozyskiwanie informacji i opinii o odczuciach, satysfakcji konsumentów, sposobie postrzegania produktów. Warto również pamiętać, że skuteczne komercjalizowanie zależy w dużej mierze od stopnia odmienności nowego produktu żywnościowego od dotychczas oferowanych. Jeśli stopień tej odmienności jest znaczny, wtedy nowy produkt ma większą szansę na uzyskanie pozytywnego i wyrazistego wizerunku w świadomości nabywców finalnych, co może pozytywnie wpłynąć na ich zachowania zakupowe, dzięki jego skutecznemu wyróżnianiu spośród innych dostępnych wyrobów (Sojkin, 2012).

\section{Konkluzja}

Szybko zmieniająca się moda na rynku, skracanie cyklu życia większości produktów, silna konkurencja, zmiana stylu życia konsumentów i poszukiwanie wciąż nowych wyzwań współprzyczyniają się do potraktowania rozwoju innowacji jako podstawowego wyzwania dla przedsiębiorców sektora żywnościowego. We współczesnym świecie coraz większą rolę odgrywają wszelkie innowacje produktowe, które z dużą częstotliwością pojawiają się na rynku. Konsumenci akceptują zwłaszcza te, które przynoszą im wymierne korzyści, np. w postaci dostarczenia organizmowi pozytywnych składników, czy też dają możliwość zaoszczędzenia czasu poświęcanego na przygotowanie posiłku dla siebie czy rodziny, który mogą z kolei alternatywnie wykorzystać na inne prace lub odpoczynek (Adamczyk, 2010).

Zrozumienie konsumenckiej percepcji innowacji staje się jednym $\mathrm{z}$ warunków rozwoju rynku produktów żywnościowych. Przeprowadzone badania pozwalają zauważyć, że postawy konsumentów wobec innowacji w badanej zbiorowości są zróżnicowane ze względu na narodowość. Analiza uzyskanych wyników badań dowodzi, że kraj pochodzenia respondentów różnicuje pojmowanie innowacji produktu żywnościowego. Badanych szczególnie dzieliło podejście do zmian w zakresie opakowań. Nasuwa się wniosek, że producenci żywności działający na przygranicznych rynkach winni skoncentrować się na budowaniu strategii działania skupionej na dyferencjacji programów marketingowych.

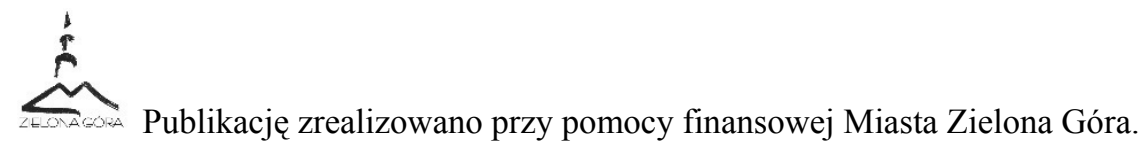




\section{Literatura}

Adamczyk, G. (2010). Popularność żywności wygodnej. Journal of Agribusiness and Rural Development, 4(18), 5-13.

Adamowicz, M. (2008). Zachowanie konsumentów w procesach adopcji innowacji na rynku owoców, W: Innowacje i innowacyjność w sektorze agrobiznesu, T. 1. Rolnictwo, przemysł spożywczy, konsumenci, M. Adamowicz (red.), Wydawnictwo SGGW, Warszawa.

Allen, J.A. (1966). Scientific innovation and industrial prosperity, Longman, London.

Babicz-Zielińska, E., Jeżewska-Zychowicz, M., Tańska, M. (2013). Neofobia a zachowania konsumentów na rynku nowej żywności. Handel Wewnętrzny, styczeń - luty.

Barska, A. (2013). Kryteria wyboru produktów żywnościowych przez młodych konsumentów z Polski, Czech i Słowacji. Zagadnienia Ekonomiki Rolnej, 3, 113-121.

Bartosik-Purgat, M. (2011). Kulturowe uwarunkowania zachowań konsumentów na przykładzie młodych Europejczyków, Wydawnictwo UE, Poznań.

Carter, C.F., Williams, B.R. (1957). Industry and technological process, Oxford University Press, London.

Choi, S.M., Ferle, C.L. (2004). Convergence across American and Korean young adults: socialisation variables indicate the verdict is still out. International Journal of Advertising, 23, 479-506.

Costa, A.I.A., Jongen, W.M.F. (2006). New insights into consumer-led food product development. Trends in Food Science\&Technology, 17, 457-465.

Cyrek, P. (2007). Innowacyjność determinantą konkurencyjności przedsiębiorstw przemysłu spożywczego, W: Transfer wiedzy i działań innowacyjnych w obszarze agrobiznesu, S. Makarski, P. Cyrek, S. Dybka, A. Kasprzyk (red.), Wydawnictwo Uniwersytetu Rzeszowskiego, Rzeszów.

Czajkowska, K., Kowalska, H., Piotrowski, D. (2013). Rola konsumenta w procesie projektowania nowych produktów spożywczych. Zeszyty Problemowe Postępów Nauk Rolniczych, 575, 23-32.

Earle, M., Earle, R., Anderson, A. (2007). Opracowywanie produktów spożywczych. Podejście marketingowe, WNT, Warszawa.

Figiel, A. (2004). Etnocentryzm konsumencki. Produkty krajowe czy zagraniczne, PWE, Warszawa.

Firlej, K., Makarska, A. (2012). Działania innowacyjne firm przemysłu spożywczego jako element ich strategii. Folia Pomeranae Universitatis Technologiae Stetinensis, Seria: Oeconomica, 297(68).

Freeman, C. (1986). The Role of Technical Change in National Economic Development, W: Technological Change, Industrial Restructuring and Regional Development, A. Amin, J. Goddard (eds.), Allan\&Unwin, London.

Freeman, C. (1994). The economics of technical change. Cambridge Journal of Economics, 18(5), 463-514.

Giddens, A. (2008). Socjologia, Wydawnictwo Naukowe PWN, Warszawa.

Griffin, R.W. (2004). Podstawy zarządzania organizacjami, Wydawnictwo Naukowe PWN, Warszawa.

Gutkowska, K., Ozimek, I. (2005). Wybrane aspekty zachowań konsumentów na rynku żywności - kryteria zróżnicowania, Wydawnictwo SGGW, Warszawa.

Gutkowska, K., Kowalczuk, I., Sajdakowska, M., Kozłowska, A., Olewnik-Mikołajewska, A., ŻakowskaBiemens, S. (2014). Postawy konsumentów wobec innowacji na rynku żywności. Handel Wewnętrzny, 4 (351), 80-93.

Gutkowska, K. (2011). Innowacyjność konsumentów wobec produktów żywnościowych jako warunek rozwoju rynku żywności. Konsumpcja i Rozwój, 1, 108-119.

Haffer, M. (1998). Determinanty strategii nowego produktu polskich przedsiębiorstw przemysłowych, UMK, Toruń.

Janasz, W., Kozioł, K. (2007). Determinanty działalności innowacyjnej przedsiębiorstw, PWE, Warszawa.

Jeżewska-Zychowicz, M., Babicz-Zielińska, E., Laskowski, W. (2009). Konsument na rynku nowej żywności. Wybrane uwarunkowania spożycia, Wydawnictwo SGGW, Warszawa.

Jeżewska-Zychowicz, M. (2009). Wybrane zachowania młodych konsumentów na rynku żywności tradycyjnej i ich uwarunkowania. Żywność Nauka Technologia Jakość, 2(93), 214-225.

Kotarba, W. (1987). Organizacja wynalazczości w przedsiębiorstwie, Zrzeszenie Wojewódzkich Klubów Techniki i Racjonalizacji, Warszawa.

Kowalczuk, I. (2011). Innowacyjna żywność w opinii konsumentów i producentów, Wydawnictwo SGGW, Warszawa.

Lenart, A. (2008A). Projektowanie nowych produktów spożywczych. Cz. I. Przemyst Spożywczy, 62 (4), 2-7.

Lenart, A. (2008B). Projektowanie nowych produktów spożywczych. Cz. II. Przemyst Spożywczy, 62 (5), 8-12.

Macdonald, D. (2002). Teoria kultury masowej, W: Kultura masowa, Cz. Milosz (red.), Wydawnictwo Literackie, Kraków.

Mazurek-Łopacińska, K. (2003). Zachowania nabywców i ich konsekwencje marketingowe, PWE, Warszawa. 
Michałowska, M., Danielak, W. (2015). Wpływ globalizacji na zachowania konsumentów w województwie lubuskim w świetle badań. Annales Universitatis Mariae Curie-Skłodowska, sectio H-Oeconomia, 49(3), $135-146$.

Mansfield, E. (1968). Industrial Research and Technology Innovation, Norton W.W. and Co., New York.

Oslo Manual (2005). Guidelines for Collecting and Interpreting Technological Innovation Data, 3rd Edition, $\mathrm{OECD} /$ Eurostat, Paris.

Parmar, A. (2002A). Global youth united: homogeneous group prime target for U.S. marketers. Marketing News, 28 October, 1-49.

Parmar, A. (2002B). Dependent variables. Marketing News, 36(19), 4.

Penc, J. (1999). Innowacje i zmiany w firmie, Placet, Warszawa.

Rogers, E.M. (2003). Diffusion of innovations, Free Press, New York.

Rowe, S., Alexander, N., Almeida, N., Black, R., Burns, R., Bush, L., Crawford, P., Keim, N., Kris-Etherton, P., Weaver, C. (2011). Food Science Challenge: Translating the Dietary Guidelines for Americans to Bring About Real Behavior Change. Journal of Food Science, January, 76(1), 29-37.

Sajdakowska, M., Żakowska-Biemans, S. (2009). Postrzeganie żywności tradycyjnej przez polskich konsumentów na podstawie badań jakościowych. Żywność. Nauka. Technologia. Jakość, 3 (64), 95-104.

Schumpeter, J.A. (1960). Teoria rozwoju gospodarczego, PWN, Warszawa.

Sikora, T. (2008). Znaczenie efektu kraju pochodzenia dla komunikacji w biznesie międzynarodowym. Zeszyty Naukowe KGŚ SGH, 23, 173-194.

Sojkin, B. (2012). Komercjalizacja produktów żywnościowych, PWE, Warszawa.

Sojkin, B., Olejniczak, T. (2012). Innowacyjność produktowa przedsiębiorstw na rynku artykułów żywnościowych. Konsumpcja i Rozwój, 1 (2), 130-140.

Sojkin, B., Małecka, M., Olejniczak, T., Bakalarska, M. (2009). Konsument wobec innowacji produktowych na rynku żywności, Wydawnictwo Uniwersytetu Ekonomicznego, Poznań.

Steenkamp, J. B. E., Ter Hofstede, F. (2002). International market segmentation: issues and perspectives. International Journal of Research in Marketing, 19(3), 185-213.

Szromnik, A., Wolanin-Jarosz, E. (2014). Etnocentryzm konsumencki na zglobalizowanym rynku-czynniki I procesy kształtowania (cz. 2). Marketing i Rynek, 4(21), 2-14.

Szwacka-Mokrzycka, J. (2013). Tendencje rozwojowe popytu i podaży żywności w Polsce, Wydawnictwo SGGW, Warszawa.

Whitfield, P.R. (1979). Innowacje w przemyśle, PWE, Warszawa.

Ustawy z dnia 25 sierpnia 2006 r. o bezpieczeństwie żywności i żywienia (Dz. U. 2006 Nr 171 poz. 1225 z późniejszymi zmianami).

Zalega, T. (2016). Nowe trendy konsumpcyjne jako przejaw innowacyjnych zachowań współczesnych konsumentów. Nierówności Społeczne a Wzrost Gospodarczy, 46, 202-225.

Zieliński, K., Żmija, D. (2013). Innovativeness in the Polish Food Industry, The International Conference Hradec Economic Days 2013: Economic Development and Management of Regions, University of Hradec Králové, Hradec Králové. 